\title{
ANTIOXIDANT-VITAMIN C: LUNG FUNCTION; LUNG CANCER
}

\author{
MAZAHAR FAROOQUI ${ }^{1}$, RAJENDRA PARDESHI ${ }^{2}$, SANTOSH JADHAV ${ }^{3}$
}

${ }^{1}$ Department of Chemistry, Dr. Rafiq Zakaria College for Women, Aurangabad, Maharashtra, India. ${ }^{2}$ Department of Chemistry, S. R. College Ghansawangi, Ghansawangi, Jalna, Maharashtra, India. ${ }^{3}$ Department of Chemistry, Vivekanand College, Aurangabad, Maharashtra, India. Email: mazaharfarooqui@gmail.com

Received: 24 May 2016, Revised and Accepted: 02 July 2016

\section{ABSTRACT}

Non-enzymatic vitamin C (ascorbic acid) plays an important role in the medicinal field and acts as antioxidants use in fruits and vegetable such as lemon, orange, grapes, carrots, tomatoes, grapefruit, beans, broccoli, and mangos. It helps to prevent and stop of various diseases such as lung cancer, asthma, and wheezing and finding an antibronchospastic effect. Other factors such as diet have also been implicated in the development of lung cancer. Despite the extensive research conducted in this area, the relationship between diet and lung cancer is still not clear. Diets high in fat and low in vegetables and fruits may increase the risk of lung cancer and other fact eating of tobacco and smoking of cigarette. Lung tissue damage due to high levels of free radicals in cigarette smoke causes direct (tissue oxidation) and indirect (release of oxidizing agents and enzymes). Vitamin C is necessary for phagocytosis. It plays a significant role in daily life, dietary system like eating food, vegetable and smoking of cigarette. It helps to prevent or stop the damage the lung tissue/or cause lung cancer. The present review studied that application of vitamin C act as antioxidant in lung cancer like diseases such as lung-cancer and role in lung function.

Keywords: Review, Non-enzymatic antioxidant (vitamin C), Lung function, Lung diseases.

(C) 2016 The Authors. Published by Innovare Academic Sciences Pvt Ltd. This is an open access article under the CC BY license (http://creativecommons. org/licenses/by/4. 0/) DOI: http://dx.doi.org/10.22159/ajpcr.2016.v9s2.13669

\section{BACKGROUND}

Since an early $18^{\text {th }}$ and/or $20^{\text {th }}$ century research on these compounds run to the discovery of vitamins:

1747 - Lind cured scurvy in British sailors with oranges and lemons.

1907 - It is reproduced experimental scurvy in guinea pigs.

1928 - Eascott identified bios-I as meso-inositol. Szent-Gyorgy and Glen published the isolation of vitamin $\mathrm{C}$ or hexuronic acid.

1933 - Allison, Hoover, and Burk describe a compound that promotes the respiration and growth of rhizobium, which designated "Coenzyme R." Then, it is defined the molecular structure and synthesis of vitamin $\mathrm{C}$.

1937 - For the determining the structure of ascorbic acid scientist "Walter Haworth" was awarded a Nobel Prize in chemistry to for his work.

1981 - Bergman et al. effect of vitamin C on bile acid pattern.

Chemistry of vitamin C

The structure of vitamin C (ascorbic acid) (Fig. a): Vitamin C is five member oxygen-containing cyclic organic compound. Oxygen containing an electron donar, and it reacted with base and abstracted proton and becomes to more nucleophilic in nature. The isomeric form (Fig. b) and act as nucleophilic in nature. It reacts with base gives ascorbate ion then speedy react with electrophile (Fig. c).

Acidity

At different levels of vitamin $\mathrm{C}$, it gives different hydrogen ion concentrations; at $\mathrm{pH} 7.4,99.95 \%$ of vitamin $\mathrm{C}$ will be present as $\mathrm{AscH}^{-}$; $0.05 \%$ as $\mathrm{AscH}_{2}$, and $0.004 \%$ as $\mathrm{Asc}^{2-}$. Thus, the antioxidant chemistry of vitamin $\mathrm{C}$ is the chemistry of $\mathrm{AscH}^{-}$(Fig. d).

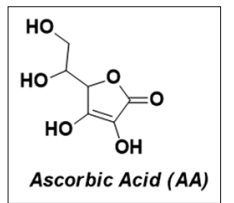

Fig. a: Ascorbic acid

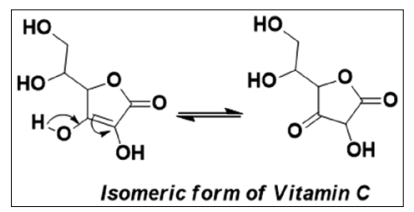

Fig. b: Isomeric form of vitamin C

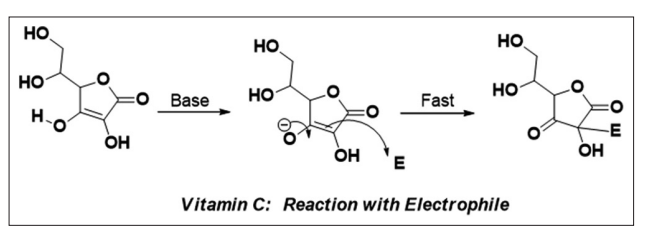

Fig. c: Electrophilic reaction of vitamin C

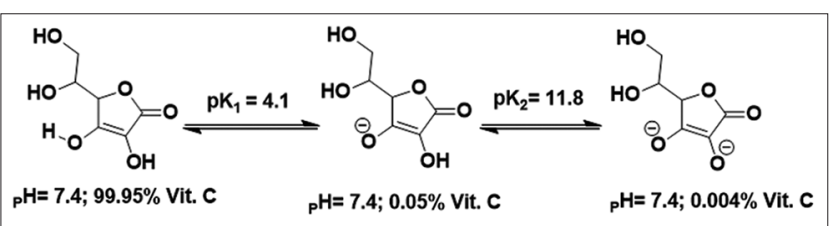

Fig. d: Acidity in different condition of vitamin C 


\section{INTRODUCTION}

An essential dietary component vitamin $\mathrm{C}$, also known as L-ascorbic acid (hexuronic acid, cevitaminic acid, or xiloascorbic acid) (Fig. 1), is a water-soluble vitamin that is naturally present in some foods, added to others, and available as a dietary supplement. Humans, unlike most animals, are unable to synthesize vitamin C endogenously [1].

Vitamin C is one of the most common antioxidants in fruits and vegetables, and it may exert chemopreventive effects [2], play a role in lung function and wheezing [2]. It has generally been acknowledged that vitamin $\mathrm{C}$ protects cells from oxidative DNA damage, thereby blocking carcinogenesis [3] The role of ascorbic acid (vitamin C) in asthma has long been argued, early as 1803 Reisseissen suggested that vitamin C prevents the wheezing observed in patients with diseases scurvy [4]. More recently, animal studies have shown that ascorbic acid may prevent anaphylaxis and other allergic phenomena $[5,6]$. In guinea pigs, ascorbic acid has been shown to reduce the airway obstruction prompted by 5-hydroxytryptamine, bradykinin, and histamine [7]. In healthy human subjects demonstrated that vitamin $\mathrm{C}$ inhibits histamine-induced bronchospasm [8]. These findings suggest that vitamin C may have an antibronchospastic effect, although some authors have failed to find evidence to support these results $[9,10]$. To further study the potential role of ascorbic acid in patients with asthma, we investigated the effect of vitamin C on exerciseinduced bronchospasm, a common asthmatic syndrome that can be easily reproduced under controlled laboratory conditions [11].

Vitamins and lung cancer [11]: Lung cancer is the most common cancer in the world. In the year 1996, an estimated 1.3 million new cases were diagnosed worldwide accounting for $12.8 \%$ of all new cases of cancer (World Cancer Research Fund and American Institute for Cancer Research, 1997). Prevention, detection, and early treatment are the tools to reduce lung cancer morbidity and mortality. Early detection of lung cancer has not been successful, as symptoms often do not appear until the disease is advanced. Similarly, screening of asymptomatic subjects with regular chest X-rays or sputum cytology has not been successful. Despite advances in the treatment of lung cancer, the 5-year survival for lung cancer is only $10-15 \%$. Thus, the only efficient way to reduce the burden from lung cancer is prevention.

Smoking of cigarette is the predominant risk factor for lung cancer; about $90 \%$ of the cases are attributable to cigarette smoking. Other risk factors for lung cancer include passive smoking, asbestos, radon, chemical carcinogens, previous chronic inflammatory lung disease, and genetic predisposition. Diet has also been implicated in the development of lung cancer. Despite the extensive research conducted in this area, the relationship between diet and lung cancer is still not clear. Diets high in fat and low in vegetables and fruits may increase the risk of lung cancer [11]. The specific mechanisms of the interaction between diet and lung cancer remain to be elucidated. As the worldwide lung cancer cause due to various polluted and/or deficiency dietary food and vegetable for the year 2011-2016 were increased (Fig. 2).

The number of epidemiologic studies has been published exploring the relationship between vitamin C intake and lung cancer risk (Fig. 3). The result of these studies are not consistent and a meta-analysis to: (1) Assess lung cancer risk for the highest versus lowest categories of vitamin C intake; (2) assess the dose-response association of lung cancer for every $100 \mathrm{mg} /$ day increment in vitamin C intake; (3) assess heterogeneity and publication bias among the studies analyzed [12]. The cancer-related deaths worldwide, furthermore, the overall survival rate for lung cancer patients is extremely low [13] such as lung cancer.

An account for a significant amount of the age-adjusted incidence rate of lung cancer was recently reported at 62.6 cases $/ 100,000$ pessople/year, and the age-adjusted death rate at 50.6 per 100,000 people/year [14]. Thus, primary prevention of lung cancer is serious. Many studies have shown that lung cancer is associated with genetic factors $[15,16]$ and environmental factors including tobacco use [17],

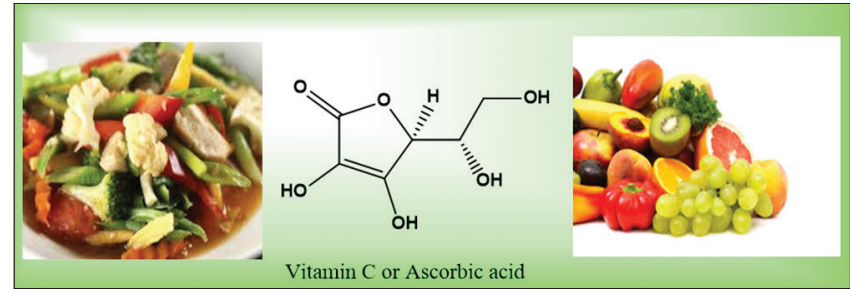

Fig. 1: Ascorbic acid in food and vegetable

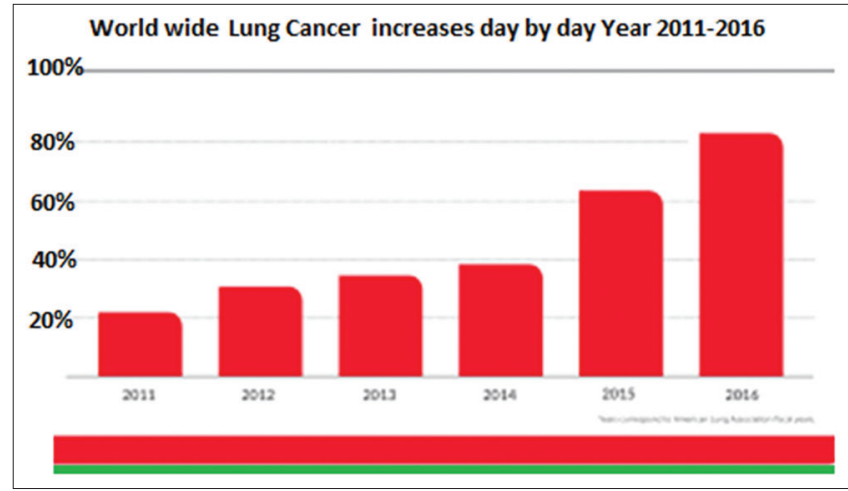

Fig. 2: Worldwide; lung cancer increase between 5 year

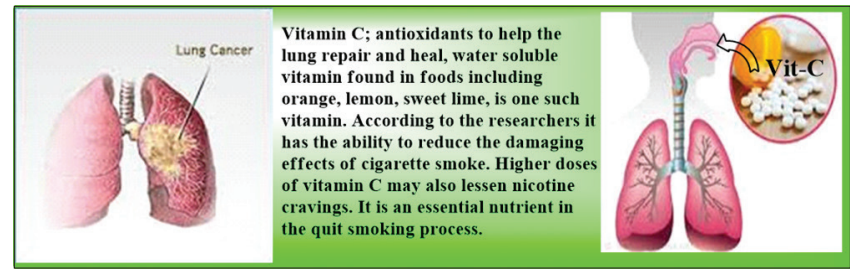

Fig. 3: Lung cancer; intake vitamin C

alcohol consumption [18], and intake of fruit, vegetables [19], and vitamins $[20,21]$ can also affect the incidence of lung cancer. The work influence that dietary factors may have upon the occurrence of this neoplasm and on the causes of possible effect [22]. Increased cancer mortality risks associated with low plasma cholesterol were not explained by the confounding effect of antioxidant vitamins but were attributed in part to the effect of preexisting cancer [23]. High levels of free radicals in cigarette smoke (CS) cause direct (tissue oxidation) and indirect (release of oxidizing agents and enzymes) damage to lung tissue [24]. About the diet, several cross-sectional epidemiological studies have suggested that dietary antioxidants and foods rich in antioxidants (i.e., fruit and vegetables) may protect the airways against oxidant-mediated damage leading to chronic obstructive airways disease (COPD) [25]. Only three longitudinal studies on the relation between diet and COPD-related outcomes have been published. In the Zutphen study, an inverse relationship was observed between baseline consumption of total and solid ( $1 / 4$ apples, pears) fruit and 25 -year incidence of chronic lung disease [26]. To observe a relationship with intake of antioxidant Vitamin $\mathrm{C}$ and $\beta$-carotene, follow-up in the other two studies was relatively duration 5-7 year [27]. Non-statistically significant longitudinal relationship between vitamin C and $\mathrm{E}$ or apple intake with pulmonary function. However, baseline apple consumption did tend to be inversely related to change in forced expiratory volume 1 [28]. In addition to the above-mentioned dietary factors with antioxidant capacities, a protective effect against the development of COPD has been suggested for fish consumption. Fish oils are thought to have anti-inflammatory effects because of the influence of the polyunsaturated fatty acids eicosapentaenoic acid and docosahexaenoic acid on arachidonic acid metabolism [29]. The cross-sectional studies published in 1990 and 1994 suggested an inverse association between 
fish consumption and COPD-related outcomes [30]. However, all crosssectional studies published in later years reported negative findings [31], no association of fish consumption with 25-year incidence of chronic lung disease was observed [32].

\section{MECHANISM AND/OR ROLE OF ANTIOXIDANTS}

Antioxidant system available to cells during oxidative stress is that of free-radical-scavenging agents. It is the first line of defense against oxygen free radicals damaging to cellular components and contributing to inflammation. In short, these agents are present to varying degrees in the intracellular and extracellular spaces, and they function by either eliminating oxidants or preventing their conversion to more toxic compounds. Normally, the lung exists in an oxygen-rich environment generated through normal cellular function or exposure to pro-oxidants and the protective activities of several intracellular and extracellular antioxidant defense systems. A tight control of redox balance is critically important for the maintenance of normal pulmonary cellular function [33]. A shift of the oxidant/antioxidant balance in favor of oxidants has been termed "oxidative stress" [34]. Researchers have hypothesized that a diet low in antioxidants such as 3-carotene, vitamins $\mathrm{C}$ and $\mathrm{E}$ may reduce natural defenses and increase susceptibility to oxidant attack and airway inflammation [33]. CS and atmospheric pollutants such as ozone $\left(\mathrm{O}_{3}\right)$ and nitrogen oxide (NO) are rich in free radicals and exposure to them can induce oxidant-mediated lung injury by direct tissue oxidation, as well as through endogenous oxidizing agents and proteolytic enzymes released after recruitment and activation of neutrophils during the inflammatory response [35]. Inhaled oxidants also amplify the effect of neutrophil proteases by oxidative deactivation of 1-proteinase inhibitor [33-36]. The antioxidant defenses of the lung have been reviewed [33,35,36]. Antioxidants may act at different levels in the oxidation process, for examples, by scavenging initiating radicals, binding metal ions, by scavenging peroxyl radicals, or by removing oxidatively damaged biomolecules [34]. Antioxidant defenses in the lung are provided by endogenous enzyme systems and non-enzymatic antioxidant compounds. The major enzymatic antioxidants are superoxide dismutase, which degrades superoxide anion, and catalase and the glutathione redox system, which inactivates hydrogen peroxide $\left(\mathrm{H}_{2} \mathrm{O}_{2}\right)$. The antioxidant defenses of the lung have been reviewed [37-39]. Non-enzymatic antioxidants such as vitamin $E$ (tocopherol), vitamin $C$ (ascorbic acid), and $\beta$-carotene (a precursor of vitamin A) Fig. 4, ubiquinone, flavonoids, and selenium are present in foods and are considered dietary antioxidants [33]. Vitamin E, a lipid-soluble vitamin, represents the body's principal defense against oxidant-induced membrane injury in human tissue, via its role in breaking the lipid peroxidation chain reaction [40]. Water-soluble vitamin C, contributes to antioxidant activity through several mechanisms, including scavenging the superoxide radical $\mathrm{O}_{2} \sim$. Vitamin $\mathrm{C}$ acts on airways by affecting arachidonic acid metabolites, particularly prostaglandins. Vitamin $\mathrm{C}$ appears to be the most abundant antioxidant substance in the extracellular fluid lining of the lung [41], and it also contributes to the regeneration of membrane-bound oxidized vitamin $\mathrm{E}$, allowing it to function again as a chain-breaking antioxidant [42]. In addition, vitamin $C$ plays a role in immune function and is transported into neutrophils and lymphocytes [36]. $\beta$-carotene, a precursor to vitamin $A$, accumulates in tissue membranes, scavenges superoxide anion, and reacts directly with peroxyl free radicals, thereby serving as a lipid-soluble antioxidant [33].

Thus, dietary intake of these vitamins may play a role in host defense against oxidative lung damage. Flavonoids such as quercetin (Fig. 5) are scavengers of superoxide anion; they exhibit singlet oxygen-quenching proprieties, scavenge lipid peroxyl radicals, and can act as chelators of iron (Fe) ions [33]. Selenium (Se) is incorporated into the antioxidant enzyme glutathione peroxidase, which reduces $\mathrm{H}_{2} \mathrm{O}_{2}$ and other organic peroxides, thereby preventing lipid peroxidation and subsequent in stability of cell membranes. Antioxidant intake may act primarily on the evolution of asthma, modulating the impact of oxidants on the lung, decreasing inflammation of the airway. Infection and inhaled pollutants activate leukocytes to produce oxidants. Neutrophils, eosinophils, and alveolar macrophages from asthmatic patients produce more reactive

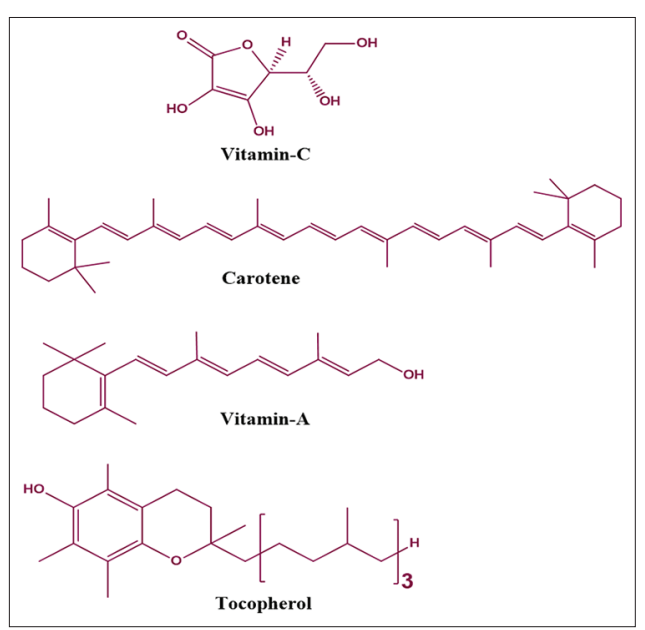

Fig. 4: Non-enzymatic antioxidants: vitamin E ( $\alpha$-tocopherol), vitamin $\mathrm{C}$ (ascorbic acid), and $\beta$-carotene

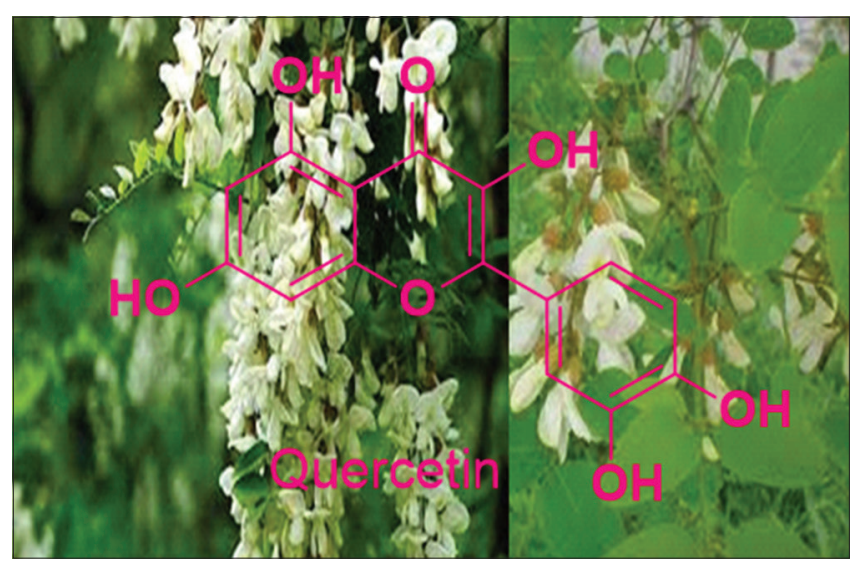

Fig. 5: Chemical structure of flavonoids-quercetin

oxygen species than do those from normal subjects. Reactive oxygen species directly contract airway smooth muscle preparation [42] and can stimulate histamine release from mast cells [41]. A number of antioxidant disturbances have also been observed in COPD patients, increase in lipid peroxidation products, and DNA damage. The Oxidative stress in chronic obstructive pulmonary disease, nutrition and metabolism of trace elements and reactive oxygen species and airway inflammation with clinical action[37, 43, 44]. Fresh fruits and vegetables contain considerable amounts of vitamin $\mathrm{C}$ (e.g., broccoli, spinach, tomatoes, and citrus fruits) and carotenoids (e.g., carrots, tomatoes, grapefruit, beans, broccoli, oranges, and mangos) [45]. The main carotenoids serving as provitamin $\beta$-carotene and cryptoxanthin may be transformed into vitamin $\mathrm{A}$. The richest sources of vitamin $\mathrm{E}$ in the human diet are oil products such as mayonnaise, vegetable and seed oils (corn, safflower, and soybean), butter, and eggs. Flavonoids are mainly found in fruits and vegetables (apples, lemons, oranges, potatoes, and cauliflower) and tea [33]. The current recommended dietary allowance requirements are $60 \mathrm{mg} /$ day for vitamin C $(100 \mathrm{mg} /$ day for smokers), 800-1000 retinol equivalents per day ( 1 retinol equivalent $=6$ (i.e., of $\beta$-carotene) for vitamin A, and 55-70 u.g/day for selenium [46].

Vitamin C contributes to antioxidant activity through several other mechanisms. It does so primarily by scavenging $\mathrm{O}_{2}$, but italso contributes to the regeneration of membrane-bound oxidized vitamin E, allowing it to function again as a chain-breaking antioxidant [47]. Dietary intake of these vitamins may, therefore, play a role in the host's defense against oxidative cell and lung damage, the oxidation of ascorbic acid using the oxidation of ascorbic acid by generate in situ $\mathrm{H}_{2} \mathrm{O}_{2}$ (hydrogen peroxide) to the dehydro ascorbate cell damage to dehydration by catalyse (Fig. 6). 


\section{VITAMIN C}

Intake of vitamin $\mathrm{C}$ vegetables and fruits having shown six prospective studies the association between these indices and lung cancer risk [48]. The results have varied from an inverse association to no association [49a-g], but three of the most recent reports have demonstrated a significant inverse association between dietary vitamin $\mathrm{C}$ and the risk of lung cancer [50a-c]. An association between plasma ascorbic acid concentration and lung cancer risk has been reported in two studies; in one study, plasma ascorbic acid was not predictive of subsequent lung cancer [51]; in another study, a modest non-significant protection was noted [52]. No controlled trials of supplementation with vitamin $\mathrm{C}$ in relation to lung cancer have been published.

Lung cancer: Tomato and/or tomato-based food-vitamin $\mathrm{C}$ as containt

A several studies view has reported an inverse association between tomato and/or lycopene intake and the risk of some types of cancer. In 2004 Food and Drug Administration (FDA) received two petitions for qualified health claims regarding tomatoes, lycopene, and the risk reduction for some forms of cancer. Here, we describe FDA's review of the scientific data for tomato and/or lycopene intake with respect to risk reduction for certain forms of cancer. The FDA found no credible evidence to support an association between lycopene intake and a reduced risk of prostate, lung and colorectal, gastric, breast, ovarian, endometrial, or pancreatic cancer. The FDA also found no credible evidence for an association between tomato consumption and a reduced risk of lung, colorectal, breast, cervical, or endometrial cancer [53]. The FDA found very limited evidence to support an association between tomato consumption and reduced risks of prostate, ovarian, gastric, and pancreatic cancers. FDA identified 18 observational studies on tomato and/or tomato-based food intake and the risk of lung cancer including three prospective cohort studies [54-56], two nested case-control studies [57,58], one case-cohort study [59], and 12 case-control studies [60-69]. Six studies [60-63,70,71] were not reviewed further. Of the 12 remaining studies, two studies [72,73] included subjects who were not pertinent to the general US population (i.e., tin miners from China), these studies pointed out that these subjects had unique environmental exposures (i.e., arsenic and severe pollution) that increased the incidence of lung cancer, and thus, their findings were not generalizable to a general population of the United States [72] Further evaluation of the 10 remaining studies revealed that seven casecontrol studies [74-80] included a greater proportion of smokers among

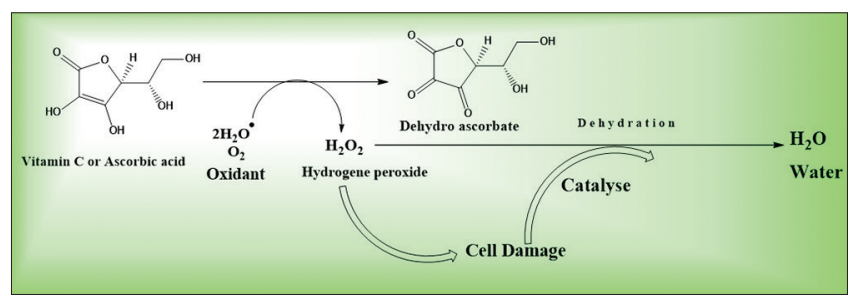

Fig. 6: Cell damage by oxidized ascorbic acid the case patients than among the control subjects and reported results that were not stratified by smoking status. Because smoking causes lung cancer $[81,82]$ and can lead to many dietary changes, including decreased weight and appetite [83], which may affect food intake and could have biased the results of these studies, it was not possible to determine whether differences in the consumption of tomatoes and/or tomato-based foods contributed independently to the results in the lung cancer case patients. Therefore, FDA concluded that scientific conclusions about the relationship between tomatoes and tomato-based food consumption and lung cancer risk could not be drawn from these seven studies, remaining three studies [84-86] were observational studies that evaluated the relationship between tomato consumption and lung cancer risk and had a high to moderate methodologic quality rating. The cohort of 89284 nurses for approximately 16 years and identified 593 cases of lung cancer [84]. They found that eating one or more servings of tomatoes per day was not associated with lung cancer incidence [85], analyzed a case-cohort of 2814 female control subjects and 138 female case patients from lowa to evaluate tomato intake and lung cancer risk. They found that tomato intake was not associated with lung cancer risk [86] conducted a nested case-control study that included a case-cohort study with 2953 control subjects and 1010 case patients from Netherlands. They observed no association between raw tomato consumption ( $25 \mathrm{~g} /$ day) and lung cancer risk. On the basis of its evaluation of these three reports, FDA concluded that there was no credible evidence supporting an association between tomato or tomato-based food consumption and lung cancer risk.

\section{Tomatoes and cancer risk reduction}

The FDA literature review on tomato consumption and cancer risk reduction; none was an interventional study that evaluated tomato consumption in subjects who had not been diagnosed with cancer [87].

A total of 64 observational studies of the association between tomato or tomato product consumption and cancer risk were identified. Of these, 25 [86,88-109] were not reviewed further because they were a republication or reanalysis of data that were already used to evaluate the health claim and/or because they had scientific deficiencies that prevented FDA from drawing scientific conclusions from the study (Table 1). For example, studies that measured biomarkers that had not been previously validated for the specific cancer under study (e.g., serum level of insulin-like growth factor and cervical dysplasia) $[110,111]$ were excluded because they did not provide reliable evidence for risk reduction, and therefore, no scientific conclusions could be drawn from them for the evaluation of a qualified health claim about cancer. Studies for which no information was provided about the validation of the food frequency questionnaire used were also excluded because failure to validate a food-frequency questionnaire may lead to false conclusions about associations between dietary factors and disease risk [112,113]. To provide no information on the accuracy of measuring tomato intake, and hence, no scientific conclusions could be drawn from them for the evaluation of a qualified health claim. One study [114] was excluded because it lacked a statistical analysis of the data, which prevented FDA from determining if there was a difference in cancer risk between subjects who did and did not consume tomatoes. Finally,

Table 1: Studies excluded from FDA's review of tomatoes and cancer risk reduction, by reason for exclusion ${ }^{a}$

\begin{tabular}{lllll}
\hline $\begin{array}{l}\text { Republication or } \\
\text { reanalysis }\end{array}$ & $\begin{array}{l}\text { Non-validated endpoint } \\
\text { of cancer }\end{array}$ & $\begin{array}{l}\text { No information on the validation of } \\
\text { the food frequency questionnaire }\end{array}$ & $\begin{array}{l}\text { No statistical } \\
\text { analysis }\end{array}$ & $\begin{array}{l}\text { No calculation of } \\
\text { risk }\end{array}$ \\
\hline Norrish, 2000 (20); & Mucci, 2001 (111); de & Seow, 2002 (113); Brennan, & Boeing, 1991 (126) & Baghurst, \\
Tzonou, 1999 (108); & Vet, 1991 (112) & 2000 (114); Norrish, 2000 (20); & $1991(127) ;$ Graham, \\
Garcia-Closase, 1998 (32); & & Cohen, 2000 (21); Mayne, 1994 (115); & $1991(128) ;$ Marshall, \\
Giovannucci, 1995 (109); & & Franceschi, 1994 (116); Levi, & $1983(129)$ \\
La Vecchia, 1987 (110) & & 1993 (117); Ramon, 1993 (118); & \\
& Fraser, 1991 (119); Hu, 1991 (120); & \\
& Bond, 1987 (121); Tuyns, 1988 (122); & \\
& & Tajima, 1985 (123); Kvale, 1983 (124); & \\
\hline
\end{tabular}

aStudies are listed by first author, year of publication (reference). FDA: Food and Drug Administration 
three studies [115-117] were excluded because they did not calculate a risk ratio, which made it impossible to determine if tomato intake reduced the risks of the cancers under study. Here, the FDA's reviews of the remaining 39 observational studies for a qualified health claim for tomatoes and tomato products by cancer type.

\section{VITAMIN CONTRIBUTING: EFFECT AND PLASMA CHAIN-BREAKING ANTIOXIDANTS}

The study complications of prematurity to result from free radical generation and an inadequacy of antioxidative capacity. The plasma total peroxyl radical-trapping capability (TRAP) and concentrations of the main chain-breaking antioxidants contributing to it, i.e., uric acid, ascorbic acid, $\alpha$-tocopherol, protein sulfhydryl groups, and bilirubin, in 21 preterm infants with a mean birth weight of $1440 \mathrm{~g}$ and gestational age of 30 weeks. The infants were divided into two groups according to their short-term outcome; the good outcome group (GOG) (n=11) with no signs of morbidity and the poor outcome group (POG) (n=10) with intraventricular hemorrhage and/or bronchopulmonary dysplasia and/ or retinopathy. Arterial blood samples were obtained 3 and 10 days postpartum. TRAP was measured with a chemiluminescent method. As a comparison, venous blood samples from 13 adults (aged from 18 to 34 ) were used. At day 3, the POG had significantly higher TRAP than the good outcome or control group, mainly because of elevated uric acid concentration. Furthermore, the concentration of unidentified antioxidants was significantly lower in GOG. By day 10, the TRAP decreased substantially in both groups. However, from the components of TRAP, both ascorbate and the unidentified fraction decreased more in POG ( $p=0.017$ and 0.021 , respectively). Furthermore, in POG on day 10 , urate concentration did not significantly differ from day 3 values. Plasma chain-break antioxidants in preterm infants with good and poor short-term outcome [118]. Some of the dietary and lung function: Smoking-environmental tobacco smoke decreases some plasma antioxidants and increases $\gamma$-tocopherol in vivo after adjustment for dietary antioxidant intakes [119-121]; Active and passive smokers are exposed to reactive free radicals that are present in CS [119]. Because free radicals cause oxidative damage to macromolecules such as lipids, proteins, and DNA, they are believed to be involved in the pathogenesis of cardiovascular diseases and cancer [120-122]. Free radicals in CS deplete some plasma antioxidants in vitro $[122,123]$, and several studies found lower plasma antioxidant concentrations in smokers in vivo [124-130]. Less information is available on the effect of CS exposure on plasma antioxidant concentrations in passive smokers [131-135]. It has been difficult to determine whether differences in plasma antioxidants between smokers and non-smokers are actually due to the effect of CS exposure or are due instead to differences in dietary antioxidant intakes or in other covariates. Epidemiologic studies showed that CS consume fewer fruits and vegetables than do non-smokers [136-140]. In addition, CS consume fewer vitamin supplements than do non-smokers [141-145]. The dietary habits of passive smokers were found to be intermediate between those of smokers and non-smokers [144]. As a result, the in vivo effect of smoking or passive smoking on plasma antioxidant status remains unclear. The study confirmed active smoking, passive smoking, or non-smoking status with plasma cotinine measures, excluded current or recent vitamin supplement users, and adjusted for dietary antioxidant intakes and other covariates. This permitted us to examine the effect of active and passive smoking on several plasma antioxidants, unconfounded by other factors. Non-smokers and passive smokers have antioxidant concentrations that are between those of smokers and nonsmokers. These results indicate that CS and non-smokers exposed to CS have a significantly lower plasma antioxidant status than do unexposed non-smokers, independent of differences in dietary antioxidant intakes. Further research is required to explain why plasma $\gamma$-tocopherol concentrations were significantly higher in smokers and passive smokers than in non-smokers [144]

\section{STUDY OF BLOOD VITAMIN C IN LUNG AND BLADDER CANCER PATIENTS BEFORE AND AFTER TREATMENT WITH ASCORBIC ACID}

A systematic study of vitamin C blood levels in patients with cancer and an evaluation of their modifications when the patients were orally treated with daily large doses of ascorbic acid ( $5 \mathrm{~g}$ /day) have been carried out. For excluding any interference on intestinal vitamin $\mathrm{C}$ absorption, all patients with digestive tract cancer have been excluded. The study has shown hypo vitaminosis $\mathrm{C}$ subclinical conditions for the greater part of subjects: In fact, the average hematic rate of ascorbic acid approaches to a lower level of physiologic range, appearing very low particularly for the younger patients. Periodic hematic dosages of vitamin $C$ of unoperable and operated patients treated with large doses of ascorbic acid have shown a rapid increase of its blood concentration which frequently has been very over $1500 \mathrm{mg} \%$, the higher level of normal range. These high vitamin hematic levels, generally constant during the time, appear useful in increasing the defense reactions of the cancerous patient [146].

\section{SEVERE HYPOVITAMINOSIS C IN LUNG CANCER PATIENTS}

The utilization of vitamin $\mathrm{C}$ in surgical repair and lymphocyte-related host resistance [147]: Plasma and buffy-coat vitamin C were estimated in 158 samples from 139 lung cancer patients, at all stages of the disease. Most samples showed hypovitaminosis C in both estimations: $64 \%$ had plasma, and $25 \%$ buffy-coat values below the thresholds for incipient clinical scurvy ( $0.3 \mathrm{mg} \%$ and $10 \mathrm{jg} / 108$ cells, respectively). Levels were diet-dependent and could be increased by oral supplements. Levels were low both in tumor-bearing patients and in those clinically free of disease after resection. The latter had particularly low values during the first 6 months, indicating the utilization of vitamin $C$ in surgical repair. The vitamin $C$ content of 13 primary lung tumors was assayed: Tumors had higher vitamin C content (mean 1116+551, ug/g tissue) than normal lung $(58.5+20-4$, ug/g). Mononuclear cells from normal individuals show a higher vitamin $\mathrm{C}$ content than polymorphs, but in lung cancer patients, the expected correlation of buffy-coat vitamin C with the proportion of lymphocytes in peripheral blood was obscured by an inverse correlation in patients with relative lymphocytosis $(25 \%$ lymphocytes), confirmed by an inverse correlation of the proportion of lymphocytes in peripheral blood with mononuclear-cell vitamin C in 14 patients in whom this was measured. These correlations were unaffected by controlling for plasma values and indicate the utilization of vitamin C in lymphocyte-related antitumor mechanisms. Vitamin C is necessary for phagocytosis and for the expression of cell-mediated immunity. In view of the increasing circumstantial evidence that immune mechanisms exert some measure of control on tumor extension and metastasis in man, the effect of supplementation with vitamin $C$ in lung cancer patients on survival should be tested in a clinical trial.

The results, over several years this laboratory has measured plasma and

Table 2: Comparison of the mean vitamin C values in normal individuals and patients with scurvy obtained in this laboratory with reports in the literature

\begin{tabular}{|c|c|c|c|c|c|}
\hline \multirow[t]{3}{*}{ Years } & \multicolumn{5}{|l|}{ Mean vitamin $\mathrm{C}$ values } \\
\hline & \multicolumn{2}{|c|}{ This laboratory (numbers in parentheses) } & \multicolumn{3}{|l|}{ Literature } \\
\hline & Buffy coat $(\mathrm{Ug} / 108$ cells) & Plasma (mg \%) & Buffy coat ( $q \operatorname{tg} / 108$ cells) & Plasma (mg \%) & Number of studies* \\
\hline$<55$ years & $31.4(46)$ & $1.03(31)$ & 29.1 & 0.88 & 7 \\
\hline$>65$ years & $25.6(88)$ & $0.45(102)$ & 20.8 & 0.45 & 13 \\
\hline Institutionalized & $10.4(142)$ & $0.18(246)$ & 14.3 & 0.22 & 25 \\
\hline Scurvy & $5.3(5)$ & $0.1(5)$ & 3.7 & 0.09 & 6 \\
\hline
\end{tabular}


leukocyte vitamin $\mathrm{C}$ in a number of population groups, many concurrent with this survey of lung cancer patients. Values in these populations agree well with the literature (Table 2) [148] and allow us to establish tentative thresholds below which plasma and leukocyte levels are associated with scurvy and hypovitaminosis C; a condition in which reduced vitamin C reserves may affect health though not leading to overt scurvy [148].

\section{CONCLUSION}

The current review studied that a role of vitamins such as C, E, and A in medicinal field, particularly in lung disease-lung cancer. Vitamin $C$ plays a significant role in daily life, dietary system like eating food, vegetable and smoking of cigarette. It helps to prevent or stop the damage the lung tissue/or cause lung cancer. The study reported that the use of vitamin $\mathrm{C}$ act as antioxidant in diseases such as lung disease, i.e., role of vitamin $\mathrm{C}$ in lung cancer.

\section{REFERENCES}

1. Li Y, Schellhorn HE. New developments and novel therapeutic perspectives for vitamin C. J Nutr 2007;137(10):2171-84

2. Mahdavi R, Faramarzi E, Seyedrezazadeh E, Mohammad-Zadeh M, Pourmoghaddam M. Evaluation of oxidative stress, antioxidant status and serum vitamin $\mathrm{C}$ levels in cancer patients. Biol Trace Elem Res 2009;130(1):1-6.

3. Pathak SK, Sharma RA, Steward WP, Mellon JK, Griffiths TR, Gescher AJ. Oxidative stress and cyclooxygenase activity in prostate carcinogenesis: Targets for chemopreventive strategies. Eur J Cancer 2005;41(1):61-70.

4. Schachter NE, Schlesinger A. The attenuation of exercise-induced bronchospasm by ascorbic acid. Anna Allergy, 1982;49:146-51.

5. Dawson W, West GB. The influence of ascorbic acid on histamine metabolism in guinea - Pigs. Br J Pharmacol Chemother 1965;24:725-34.

6. Guirgis HM. Anti - Anaphylactic effect of Vitamin c in the guinea - Pig J Pharm Pharmacol 1965;17:387.

7. Dawson W, Hemsworth BA, Stockham MA. Actions of sodium ascorbate on smooth muscle. Br J Pharmacol Chemother 1967;31(2):269-75.

8. Zuskin E, Lewis AJ, Bouhuys A. Inhibition of histamine-induced airway constriction by ascorbic acid. J Allergy Clin Immunol 1973;51(4):218-26.

9. Kreisman H, Mitchell C, Bouhuys A. Inhibition of histamin-induced airway constriction negative results with oxtriphylline and ascorbic acid. Lung 1977;154:223-9.

10. Kordansky DW, Rosenthal RR, Norman PS. The effect of vitamin $\mathrm{C}$ on antigen-induced bronchospasm. J Allergy Clin Immunol 1979;63(1):61-4.

11. (a) Anderson SD, Silverman M, König P, Godfrey S. Exerciseinduced asthma. Br J Dis Chest 1975;69(1):1-39. (b) National Public Health Institute. Proceedings of the Nutrition Society. Vol. 58. Helsinki, Finland: National Public Health Institute; 1999. p. 329-33. (c) Ziegler RG, Mayne ST, Swanson CA. Nutrition and lung cancer. Cancer Causes Control 1996;7(1):157-77.

12. Luo J, Shen L, Zheng D. Association between vitamin C intake and lung cancer: A dose-response meta-analysis. Sci Rep 2014;4:6161.

13. Herbst RS, Heymach JV, Lippman SM. Lung cancer. N Engl J Med 2008;359(13):1367-80.

14. Wang J, Li C, Tao H, Cheng Y, Han L, Li X, et al. Statin use and risk of lung cancer: A meta-analysis of observational studies and randomized controlled trials. PLoS One 2013;8:e77950.

15. Li H, Hao X, Zhang W, Wei Q, Chen K. The hOGG1 Ser326Cys polymorphism and lung cancer risk: A meta-analysis. Cancer Epidemiol Biomarkers Prev 2008;17:1739-45

16. Lu X, Ke J, Luo X, Zhu Y, Zou L, Li H, et al. The SNP rs402710 in 5 p15.33 is associated with lung cancer risk: A replication study in Chinese population and a meta-analysis. PLoS One 2013;8(10):e76252.

17. Kim $\mathrm{CH}$, Lee YC, Hung RJ, McNallan SR, Cote ML, Lim WY, et al. Exposure to secondhand tobacco smoke and lung cancer by histological type: A pooled analysis of the International Lung Cancer Consortium (ILCCO). Int J Cancer 2014;135(8):1918-30.

18. Druesne-Pecollo N, Keita Y, Touvier M, Chan DS, Norat T, Hercberg S, et al. Alcohol drinking and second primary cancer risk in patients with upper aerodigestive tract cancers: A systematic review and metaanalysis of observational studies. Cancer Epidemiol Biomarkers Prev 2014;23:324-31.
19. Norat T, Aune D, Chan D, Romaguera D. Fruits and vegetables: Updating the epidemiologic evidence for the WCRF/AICR lifestyle recommendations for cancer prevention. Cancer Treat Res 2014:159:35-50

20. Redaniel MT, Gardner MP, Martin RM, Jeffreys M. The association of vitamin D supplementation with the risk of cancer in postmenopausal women. Cancer Causes Control 2014;25:267-71.

21. Cheng TY, Lacroix AZ, Beresford SA, Goodman GE, Thornquist MD, Zheng Y, et al. Vitamin D intake and lung cancer risk in the Women's Health Initiative. Am J Clin Nutr 2013;98:1002-11.

22. Ruano-Ravina A, Figueiras A, Barros-Dios JM. Diet and lung cancer: A new approach. Eur J Cancer Prev 2000;9:395-400.

23. Eichholzer M, Stähelin HB, Gutzwiller F, Lüdin E, Bernasconi F. Association of low plasma cholesterol with mortality for cancer at various sites in men: 17-y follow-up of the prospective Basel study. Am J Clin Nutr 2000;71:569-74.

24. Chow CK. Cigarette smoking and oxidative damage in the lung. Ann N Y Acad Sci 1993;686:289-98.

25. (a) Smit HA, Grievink L, Tabak C. Dietary influences on chronic obstructive lung disease and asthma: A review of the epidemiological evidence. Proc Nutr Soc 1999;58(2):309-19. (b) Tabak C, Smit HA Räsänen L, Fidanza F, Menotti A, Nissinen A, et al. Dietary factors and pulmonary function: A cross sectional study in middle aged men from three European countries. Thorax 1999;54:1021-6. (c) Butland BK, Fehily AM, Elwood PC. Diet, lung function, and lung function decline in a cohort of 2512 middle aged men. Thorax 2000;55(2):102-8

26. Miedema I, Feskens EJ, Heederik D, Kromhout D. Dietary determinants of long-term incidence of chronic nonspecific lung diseases. The Zutphen Study. Am J Epidemiol 1993;138:37-45.

27. (a) Kang JH, Cook NR, Manson JE, Buring JE, Albert CM, Grodstein F. Vitamin E, Vitamin C and $\beta$-carotene and cognitive function among women with or at risk of cardiovascular disease: The Women's Antioxidant and Cardiovascular study. Circulation 2009;119(21):2772-80. (b) Kim DO, Lee KW, Lee HJ, Lee CY. Vitamin $\mathrm{C}$ equivalent antioxidant capacity (VCEAC) of phenolic, phytochemicals. J Agric Food Chem 2002;50:3713-7.

28. Carey IM, Strachan DP, Cook DG. Effects of changes in fresh fruit consumption on ventilatory function in healthy British adults. Am J Respir Crit Care Med 1998;158:728-33.

29. Sperling RI. Effects of dietary fish oil on leukocyte leukotriene and PAF generation and on neutrophil chemotaxis. World Rev Nutr Diet 1991;66:391-400

30. Smit HA, Grievink L, Tabak C. Dietary influences on chronic obstructive lung disease and asthma: A review of the epidemiological evidence. Proc Nutr Soc 1999;58(3):309-19.

31. (a) Cook DG, Carey IM, Whincup PH, Papacosta O, Chirico S, Bruckdorfer KR, et al. Effect of fresh fruit consumption on lung function and wheeze in children. Thorax 1997;52:628-33. (b) Fluge O, Omenaas E, Eide GE, Gulsvik A. Fish consumption and respiratory symptoms among young adults in a Norwegian community. Eur Respir J 1998;12:336-340.

32. (a) Varraso R, Barr RG, Willett WC, Speizer FE, Camargo CA Jr. Fish intake and risk of chronic obstructive pulmonary disease in 2 large US cohorts. Am J Clin Nutr 2015;101(1):354-61. (b) Smit HA, Grievink L, Tabak C. Dietary influences on chronic obstructive lung disease and asthma: A review of the epidemiological evidence. Proc Nutr Soc 1999;58(2):309-19.

33. Romieu I, Trenga C. Diet and obstructive lung diseases. Epidemiol Rev 2001;23(2):268-87.

34. (a) Sies H, editor. Oxidative stress, introduction. In: Oxidative Stress: Oxidants and Antioxidants. San Diego, CA: Academic Press, Inc.; 1991. p. 15-22. (b) Krishnaveni M. Antioxidant activity of selected plants. Int J Pharm Pharm Sci 2014;6(2):126-8.

35. McGowan SE, Hunninghake GW. Neutrophils and emphysema N Engl J Med 1989;321:968-70.

36. Sibille Y, Reynolds HY. Macrophages and polymorphonuclear neutrophils in lung defense and injury. Am Rev Respir Dis 1990;141(2):471-501.

37. Repine JE, Bast A, Lankhorst I. Oxidative stress in chronic obstructive pulmonary disease. Oxidative Stress Study Group. Am J Respir Crit Care Med 1997; 156:341-57.

38. Bast A, Haenen GR, Doelman CJ. Oxidants and antioxidants: State of the art. Am J Med 1991;91(3C):2S-13.

39. Cantin A, Crystal RG. Oxidants, antioxidants and the pathogenesis of emphysema. Eur J Respir Dis Suppl 1985;139:7-17.

40. Burton GW, Ingold KU. Autooxidation of biological molecules. 1. 
The antioxidant activity of Vitamin E and related chain - Breaking phenolic antioxidants in vitro. J Am Chem Soc 1981;103:6472-7.

41. Hatch GE. Asthma, inhaled oxidants, and dietary antioxidants. Am J Clin Nutr 1995;61 3 Suppl:625S-30.

42. Mc Cay PB. Vitamin E: Interactions with free radicals and ascorbate. Annu Rev Nutr 1985;5:323-40.

43. Linder MC, editor. Nutrition and metabolism of trace elements. In: Nutrition Biochemistry and Metabolism with Clinical Application. Norwalk, CT: Appleton and Lange; 1991. p. 213-76.

44. Barnes PJ. Reactive oxygen species and airway inflammation. Free Radic Biol Med 1990;9(3):235-43.

45. Romieu I, Stampfer MJ, Stryker WS, Hernandez M, Kaplan L, Sober A, et al. Food predictors of plasma beta-carotene and alphatocopherol: Validation of a food frequency questionnaire. Am J Epidemiol 1990;131(5):864-76.

46. National Research Council. Recommended Dietary Allowances. $10^{\text {th }}$ ed. Washington, DC: National Academy Press; 1989.

47. Young IS, Woodside JV. Antioxidants in health and disease. J Clin Pathol 2001;54(3):176-86.

48. National Public Health Institute. Proceedings of the Nutrition Society. Helsinki, Finland: National Public Health Institute; 1999. p. 329-33.

49. (a) Kvale G, Bjelke E, Gart JJ. Dietary habits and lung cancer risk. Int J Cancer 1983;31:397-405. (b) Kromhout D. Essential micronutrients in relation to carcinogenesis. Am J Clin Nutr 1987;45 5 Suppl:1361-7. (c) Knekt P, Järvinen R, Seppänen R, Rissanen A, Aromaa A, Heinonen OP, et al. Dietary antioxidants and the risk of lung cancer. Am J Epidemiol 1991;134:471-9. (d) Chow WH, Schuman LM, McLaughlin JK, Bjelke E, Gridley G, Wacholder S, et al. A cohort study of tobacco use, diet, occupation, and lung cancer mortality. Cancer Causes Control 1992;3(5):247-54. (e) Shibata A, PaganiniHill A, Ross RK, Henderson BE. Intake of vegetables, fruits, betacarotene, vitamin $\mathrm{C}$ and vitamin supplements and cancer incidence among the elderly: A prospective study. Br J Cancer 1992;66(3):673-9. (f) Steinmetz KA, Potter JD, Folsom AR. Vegetables, fruit, and lung cancer in the Iowa Women's Health Study. Cancer Res 1993;53(3):53643. (g) Elgadir MA, Salama M, Adam A. Anti - Breast cancer from various natural sources - Review. Int J Pharm Pharm Sci 2015;7(2):44-7.

50. (a) Bandera EV, Freudenheim JL, Marshall JR, Zielezny M, Priore RL, Brasure $\mathrm{J}$, et al. Diet and alcohol consumption and lung cancer risk in the New York State Cohort (United States) Cancer Causes Control 1997;8(3):828-40. (b) Ocké MC, Bueno-de-Mesquita HB, Feskens EJ, van Staveren WA, Kromhout D. Repeated measurements of vegetables, fruits, beta-carotene, and vitamins $\mathrm{C}$ and $\mathrm{E}$ in relation to lung cancer. The Zutphen Study. Am J Epidemiol 1997;145(6):358-65. (c) Yong LC, Brown CC, Schatzkin A, Dresser CM, Slesinski MJ, Cox CS, et al. Intake of vitamins $\mathrm{E}, \mathrm{C}$, and A and risk of lung cancer. The NHANES I epidemiologic follow up study. First National Health and Nutrition Examination Survey. Am J Epidemiol 1997;146(4):231-43.

51. Stahelin HB, Gey KF, Eichholzer M, Lüdin E, Bernasconi F, Thurneysen $\mathrm{J}$, et al. Plasma antioxidant vitamins and subsequent cancer mortality in the 12-year follow-up of the prospective Basel Study. Am J Epidemiol 1991;133(2):766-75.

52. Comstock GW, Alberg AJ, Huang HY, Wu K, Burke AE, Hoffman SC, et al. The risk of developing lung cancer associated with antioxidants in the blood: Ascorbic acid, carotenoids, a - Tocopherol, selenium, and total peroxyl radical absorbing capacity. Cancer Epidemiol Biomarkers Prev 1997;6:907-16.

53. Kavanaugh CJ, Trumbo PR, Ellwood KC. The U.S. Food and Drug Administration's evidence-based review for qualified health claims: tomatoes, lycopene, and cancer. J Natl Cancer Inst 2007;99:14.

54. (a) Savage L, Widener ZA. FDA finds no strong link between tomatoes and reduced cancer risk. J Natl Cancer Inst. Available from: http://www.jncimedia@oxfordjournals.org.z 301-841-1287. (b) Kavanaugh CJ, Trumbo PR, Ellwood KC. The U.S. food and drug administration's evidence-based review for qualified health claims: Tomatoes, lycopene, and cancer. J Natl Cancer Inst 2007;99:1074-85.

55. Kvale G, Bjelke E, Gart JJ. Dietary habits and lung cancer risk. Int J Cancer 1983;31(4):397-405.

56. Park Y, Hunter DJ, Spiegelman D, Bergkvist L, Berrino F, van den Brandt PA, et al. Dietary fiber intake and risk of colorectal cancer: A pooled analysis of prospective cohort studies. JAMA 2005;294(22):2849-57.

57. Van den Brandt PA, Goldbohm RA, van 't Veer P, Volovics A, Hermus RJ, Sturmans F. A large-scale prospective cohort study on diet and cancer in the Netherlands. J Clin Epidemiol 1990;43(3):285-95.

58. Steinmetz KA, Potter JD, Folsom AR. Vegetables, fruit and lung cancer in the Iowa women's health study. Cancer Res
1993;53(3):536-43

59. Cho E, Smith-Warner SA, Ritz J, van den Brandt PA, Colditz GA, Folsom AR, et al. Alcohol intake and colorectal cancer: A pooled analysis of 8 cohort studies. Ann Intern Med 2004;140(8):603-13.

60. Garcia-Closas R, Agudo A, Gonzalez CA, Riboli E. Intake of specific carotenoids and flavonoids and the risk of lung cancer in women in Barcelona, Spain. Nutr Cancer 1998;32(3):154-8.

61. Levy PS, Roth HD, Deubner DC. Exposure to beryllium and occurrence of lung cancer: A reexamination of findings from a nested case-control study. J Occup Environ Med 2007;49(1):96-101.

62. Howe GR, Hirohata T, Hislop TG, Iscovich JM, Yuan JM, Katsouyanni $\mathrm{K}$, et al. Dietary factors and risk of breast cancer: Combined analysis of 12 case-control studies. J Natl Cancer Inst 1990;82(7):561-9.

63. (a) Forman MR, Yao SX, Graubard BI, Qiao YL, McAdams M, Mao BL, et al. The effect of dietary intake of fruits and vegetables on the odds ratio of lung cancer among Yunnan tin miners. Int J Epidemiol 1992;21(3):437-41. (b) Fraser GE, Beeson WL, Phillips RL. Diet and lung cancer in California seventh day adventists. Am J Epidemiol 1991;133(7):683-93.

64. Harris R, Whittemore AS, Itnyre J. Characteristics relating to ovarian cancer risk: Collaborative analysis of 12 US case-control Studies, III. Epithelial tumors of low malignant potential in white women. Collaborative ovarian cancer group. Am J Epidemiol 1992;136(10):1204-11.

65. Vandenbroucke JP, Pearce N. Case-control studies: Basic concepts. Int J Epidemiol 2012;41(5):1480-9.

66. Song JW, Chung KC. Observational studies: Cohort and case-control studies, Plast Reconstr Surg 2010;126(6):2234-42.

67. Forman D, Epidemiology and Health Services Research. Gastric cancer and Helicobacter pylori: A combined analysis of 12 case control studies nested within prospective cohorts. Gut 2001;49:347-353. DOI:10.1136/gut.49.3.347.

68. Khoury MJ, Flanders WD. Nontraditional epidemiologic approaches in the analysis of gene environment interaction: Case - Control studies with no controls. Am J Epidemiol 1996;144(3):207-13.

69. Mann CJ. Observational research methods. Research design II: Cohort, cross sectional, and case-control studies. Emerg Med J 2003;20(1):54-60.

70. Greenland S. Model-based estimation of relative risks and other epidemiologic measures in studies of common outcomes and in casecontrol studies. Am J Epidemiol 2004;160(4):301-5.

71. Howe GR, Hirohata T, Hislop TG, Iscovich JM, Yuan JM, Katsouyanni K, et al. Dietary factors and risk of breast cancer: Combined analysis of 12 case-control studies. J Natl Cancer Inst 1990;82(7):561-9.

72. Forman MR, Yao SX, Graubard BI, Qiao YL, McAdams M, Mao BL, et al. The effect of dietary intake of fruits and vegetables on the odds ratio of lung cancer among Yunnan tin miners. Int J Epidemiol 1992;21(3):437-41.

73. Marshall HM, Bowman RV, Yang IA, Fong KM, Berg CD. Screening for lung cancer with low-dose computed tomography: A review of current status. J Thorac Dis 2013;5 Suppl 5:S524-39.

74. (a) Kreuzer M, Krauss M, Kreienbrock L, Jöckel KH, Wichmann HE. Environmental tobacco smoke and lung cancer: A case-control study in Germany. Am J Epidemiol 151(3):241-50. (b) Aldington S, Harwood M, Cox B, Weatherall M, Beckert L, Hansell A, et al. Cannabis use and risk of lung cancer: A case-control study. Eur Respir J 2008;31(2):280-6.

75. (a) Key TJ, Schatzkin A, Willett WC, Allen NE, Spencer EA, Travis RC. Diet, nutrition and the prevention of cancer. Public Health Nutr 2004;7(1A):187-200. (b)Tan HL, Thomas-Ahner JM, Grainger EM, Wan L, Francis DM, Schwartz SJ, et al. Tomato-based food products for prostate cancer prevention: What have we learned? Cancer Metastasis Rev 2010;29(3):553-68.

76. Gallicchio L, Boyd K, Matanoski G, Tao XG, Chen L, Lam TK, et al. Carotenoids and the risk of developing lung cancer: A systematic review. Am J Clin Nutr 2008;88(2):372-83.

77. Yuan JM, Ross RK, Chu XD, Gao YT, Yu MC. Prediagnostic levels of serum beta-cryptoxanthin and retinol predict smoking-related lung cancer risk in Shanghai, China. Cancer Epidemiol Biomarkers Prev 2001;10(7):767-73.

78. Mayne ST, Janerich DT, Greenwald P, Chorost S, Tucci C, Zaman MB, et al. Dietary beta carotene and lung cancer risk in U.S. nonsmokers. J Natl Cancer Inst 1994;86(1):33-8.

79. Brennan P, Fortes C, Butler J, Agudo A, Benhamou S, Darby S, et al. A multicenter case-control study of diet and lung cancer among nonsmokers. Cancer Causes Control 2000;11(1):49-58. 
80. Mathew A, Gangadharan P, Varghese C, Nair MK. Diet and stomach cancer: A case-control study in South India. Eur J Cancer Prey 2000;9(2):89-97.

81. Montesano R, Hall J. Environmental causes of human cancers. Eur J Cancer 2001;37 Suppl 8:S67-87.

82. Doll R. Uncovering the effects of smoking: Historical perspective. Stat Methods Med Res 1998;7(2):87-117.

83. Jo YH, Talmage DA, Role LW. Nicotinic receptor-mediated effects on appetite and food intake. J Neurobiol 2002;53(4):618-32.

84. Richard H, Andrea V, Sarah L, John B. Lung cancer and cryptogenic fibrosing alveolitis. Am J Respir Critic Care Med 2000;161(1):5-8.

85. Lippi G, Targher G. Tomatoes, lycopene-containing foods and cancer risk. J Cancer 2011;104(7):1234-5

86. Kirsh VA, Mayne ST, Peters U, Chatterjee N, Leitzmann MF, Dixon LB, et al. A prospective study of lycopene and tomato product intake and risk of prostate cancer. Cancer Epidemiol Biomarkers Prev 2006;15(1):92-8

87. (a) Kavanaugh CJ, Trumbo PR, Ellwood KC. The U.S. Food and drug administration's evidence-based review for qualified health claims: Tomatoes, lycopene, and cancer. J Natl Cancer Ins 2007;99(14):1074-1085. (b) Mills PK, Beeson L, Abbey DE, Fraser GE, Phillips RL. Dietary habits and past medical history as related to fata pancreas cancer risk among Adventists. Cancer 1988;61(12):2578-85.

88. Cohen JH, Kristal AR, Stanford JL. Fruit and vegetable intakes and prostate cancer risk. J Natl Cancer Inst 2000;92(1):61-8.

89. Deneo-Pellegrini H, De Stefani E, Ronco A, Mendilaharsu M. Foods, nutrients and prostate cancer: A case - control study in Uruguay. Br J Cancer 1999;80(3-4):591-7.

90. La Vecchia C, Braga C, Negri E, Franceschi S, Russo A, Conti E, et al. Intake of selected micronutrients and risk of colorectal cancer. Int J Cancer 1997;73(4):525-30.

91. Tzonou A, Signorello LB, Lagiou P, Wuu J, Trichopoulos D, Trichopoulou A. Diet and cancer of the prostate: A case-control study in Greece. Int J Cancer 1999;80(5):704-8.

92. Giovannucci E, Ascherio A, Rimm EB, Stampfer MJ, Colditz GA, Willett WC. Intake of carotenoids and retinol in relation to risk of prostate cancer. J Natl Cancer Inst 1995;87(23):1767-76.

93. La Vecchia C, Negri E, Decarli A, D’Avanzo B, Franceschi S. A casecontrol study of diet and gastric cancer in northern Italy. Int J Cancer 1987;40(4):484-9

94. Ellinger S, Ellinger J, Stehle P. Tomatoes, tomato products and lycopene in the prevention and treatment of prostate cancer: Do we have the evidence from intervention studies? Curr Opin Clin Nutr Metab Care 2006;9(6):722-7.

95. Seow A, Quah SR, Nyam D, Straughan PT, Chua T, Aw TC. Food groups and the risk of colorectal carcinoma in an Asian population. Cancer 2002;95(11):2390-6.

96. Hwang ES, Bowen PE. Can the consumption of tomatoes or lycopene reduce cancer risk? Integr Cancer Ther 2002;1(2):121-32.

97. Giovannucci E. Tomatoes, tomato-based products, lycopene, and cancer: Review of the epidemiologic literature. J Natl Cancer Inst 1999;91(4):317-31.

98. Franceschi S, Bidoli E, La Vecchia C, Talamini R, D’Avanzo B, Negri E. Tomatoes and risk of digestive-tract cancers. Int J Cancer 1994;59(2):181-4.

99. Levi F, Franceschi S, Negri E, La Vecchia C. Dietary factors and the risk of endometrial cancer. Cancer 1993;71(11):3575-81.

100. Ramón JM, Serra L, Cerdó C, Oromí J. Dietary factors and gastric cancer risk. A case-control study in Spain. Cancer 1993;71(4):1731-5.

101. Giovannucci E. A review of epidemiologic studies of tomatoes, lycopene, and prostate cancer. Exp Biol Med (Maywood) 2002;227(10):852-9

102. Hu JF, Liu YY, Yu YK, Zhao TZ, Liu SD, Wang QQ. Diet and cancer of the colon and rectum: A case-control study in China. Int J Epidemiol 1991;20(2):362-7

103. Giovannucci E, Rimm EB, Liu Y, Stampfer MJ, Willett WC A prospective study of tomato products, lycopene, and prostate cancer risk. J Natl Cancer Inst 2002;94(5):391-8.

104. Tuyns AJ, Kaaks R, Haelterman M. Colorectal cancer and the consumption of foods: A case-control study in Belgium. Nutr Cancer 1988;11(3):189-204

105. Tajima K, Tominaga S. Dietary habits and gastro-intestinal cancers: A comparative case-control study of stomach and large intestinal cancers in Nagoya, Japan. Jpn J Cancer Res 1985;76(8):705-16.

106. Holick CN1, Michaud DS, Stolzenberg-Solomon R, Mayne ST, Pietinen P, Taylor PR, et al. Dietary carotenoids, serum $\beta$-carotene, and retinol and risk of lung cancer in the alpha-tocopherol, beta- carotene cohort study. Am J Epidemiol 2002;156(6):536-47.

107. Haenszel W, Kurihara M, Segi M, Lee RK. Stomach cancer among Japanese in Hawaii. J Natl Cancer Inst 1972;49:969-88.

108. Marti R, Roselló S, Cebolla-Cornejo J. Tomato as a source of carotenoids and polyphenols targeted to cancer prevention. Cancers (Basel) 2016;8(6):pii: E58.

109. Rimm EB, Liu Y, Stampfer MJ, Willett WC. A prospective study of tomato products, lycopene, and prostate cancer risk. J Natl Cancer Inst 2002;94(5):112.

110. Lazarenko LM, Nikitina OE, Nikitin EV, Demchenko OM, Kovtonyuk GV, Ganova LO, et al. Development of biomarker pane to predict, prevent and create treatments tailored to the persons with human papillomavirus - Induced cervical precancerous lesions. EPMA J 2014;5(1):1.

111. Bowen P, Chen L, Stacewicz-Sapuntzakis M, Duncan C, Sharifi R, Ghosh L, et al. Tomato sauce supplementation and prostate cancer: Lycopene accumulation and modulation of biomarkers of carcinogenesis. Exp Biol Med (Maywood) 2002;227(10):886-93.

112. Cade J, Thompson R, Burley V, Warm D. Development, validation and utilisation of food-frequency questionnaires - A review. Public Health Nutr 2002;5:567-87.

113. Subar AF, Thompson FE, Kipnis V, Midthune D, Hurwitz P, McNutt S, et al. Comparative validation of the Block, Willett, and National Cancer Institute food frequency questionnaires: The Eating at America's Table Study. Am J Epidemiol 2001;154(12):1089-99.

114. Anand P, Kunnumakara AB, Sundaram C, Harikumar KB Tharakan ST, Lai OS, et al. Cancer is a preventable disease that requires major lifestyle changes. Pharm Res 2008;25(9):2097-116.

115. Chen J, Song Y, Zhang L. Lycopene/tomato consumption and the risk of prostate cancer: A systematic review and meta-analysis of prospective studies, J Nutr Sci Vitaminol (Tokyo) 2013;59(3):213-23.

116. Miller EC, Giovannucci E, Erdman JW Jr, Bahnson R, Schwartz SJ Clinton SK. Tomato products, lycopene, and prostate cancer risk, Urol Clin North Am 2002;29(1):83-93.

117. Graff RE, Pettersson A, Lis RT, Ahearn TU, Markt SC, Wilson KM, et al. Dietary lycopene intake and risk of prostate cancer defined by ERG protein expression. Am J Clin Nutr 2016;103(3):851-60.

118. Luukkainen P, Aejmelaeus R, Alho H, Metsä-Ketelä T, Ikonen SR, Salo MK. Plasma chain-breaking antioxidants in preterm infants with good and poor short-term outcome. Free Radic Res 1999;30(3):189-97

119. Pryor WA, Stone K. Oxidants in cigarette smoke. Radicals, hydrogen peroxide, peroxynitrate, and peroxynitrite. Ann N Y Acad Sci 1993;686:12-27.

120. Pryor WA. Cigarette smoke and the involvement of free radica reactions in chemical carcinogenesis. Br J Cancer Suppl 1987;8:19-23.

121. Pryor WA Cancer and free radicals. In: Shankel DM, editor. Antimutagenesisand Anticarcinogenesis: Mechanisms. New York: Plenum Press; 1986. p. 45-59.

122. Frei B, Forte TM, Ames BN, Cross CE. Gas phase oxidants of cigarette smoke induce lipid peroxidation and changes in lipoprotein properties in human blood plasma. Protective effects of ascorbic acid. Biochem J 1991;277:133-8.

123. Diplock AT, Charleux JL, Crozier-Willi G, Kok FJ, Rice-Evans C, Roberfroid M, et al. Functional food science and defence against reactive oxidative species. Br J Nutr 1998;80 Suppl 1:S77-112.

124. Eiserich JP, van der Vliet A, Handelman GJ, Halliwell B, Cross CE. Dietary antioxidants and cigarette smoke-induced biomolecular damage: A complex interaction. Am J Clin Nut 1995;62 6 Suppl:1490S-500.

125. Mezzetti A, Lapenna D, Pierdomenico SD, Calafiore AM, Costantini F, Riario-Sforza G, et al. Vitamins E, C and lipid peroxidation in plasma and arterial tissue of smokers and non-smokers. Atherosclerosis 1995;112(1):91-9.

126. Schectman G, Byrd JC, Gruchow HW. The influence of smoking on vitamin C status in adults. Am J Public Health 1989;79(2):158-62.

127. Marangon K, Herbeth B, Lecomte E, Paul-Dauphin A, Grolier P, Chancerelle Y, et al. Diet, antioxidant status, and smoking habits in French men. Am J Clin Nutr 1998;67(2):231-9.

128. Lykkesfeldt J, Christen S, Wallock LM, Chang HH, Jacob RA, Ames BN. Ascorbate is depleted by smoking and repleted by moderate supplementation: A study in male smokers and nonsmokers with matched dietary antioxidant intakes. Am J Clin Nutr 2000;71:530-6.

129. Ross MA, Crosley LK, Brown KM, Duthie SJ, Collins AC, Arthur JR, et al. Plasma concentrations of carotenoids and antioxidant vitamins in Scottish males: Influences of smoking. Eur J Clin Nutr 1995;49:861-5.

130. Norkus EP, Hsu H, Cehelsky MR. Effect of cigarette smoking on the 
Vitamin C status of pregnant women and their offspring. Ann N Y Acad Sci 1987;498:500-1.

131. Stryker WS, Kaplan LA, Stein EA, Stampfer MJ, Sober A, Willett WC The relation of diet, cigarette smoking, and alcohol consumption to plasma beta-carotene and alpha-tocopherol levels. Am J Epidemiol 1988;127(2):283-96.

132. Valkonen M, Kuusi T. Passive smoking induces atherogenic changes in low-density lipoprotein. Circulation 1998;97(1):2012-6.

133. Tribble DL, Giuliano LJ, Fortmann SP. Reduced plasma ascorbic acid concentrations in nonsmokers regularly exposed to environmental tobacco smoke. Am J Clin Nutr 1993;58(6):886-90.

134. Alberg AJ, Chen JC, Zhao H, Hoffman SC, Comstock GW, Helzlsouer KJ. Household exposure to passive cigarette smoking and serum micronutrient concentrations. Am J Clin Nutr 2000;72(6):1576-82.

135. Farchi S, Forastiere F, Pistelli R, Baldacci S, Simoni M, Perucci CA, et al. Exposure to environmental tobacco smoke is associated with lower plasma beta-carotene levels among nonsmoking women married to a smoker. Cancer Epidemiol Biomarkers Prev 2001;10(8):907-9.

136. Ayaori M, Hisada T, Suzukawa M, Yoshida H, Nishiwaki M, Ito T, et al. Plasma levels and redox status of ascorbic acid and levels of lipid peroxidation products in active and passive smokers. Environ Health Perspect 2000;108(2):105-8.

137. Dallongeville J, Marécaux N, Fruchart JC, Amouyel P. Cigarette smoking is associated with unhealthy patterns of nutrient intake: A meta-analysis. J Nutr 1998;128(2):1450-7.

138. Wei W, Kim Y, Boudreau N. Association of smoking with serum and dietary levels of antioxidants in adults: NHANES III, 1988-1994. Am J Public Health 2001;91(2):258-64.

139. Ma J, Hampl JS, Betts NM. Antioxidant intakes and smoking status:
Data from the continuing survey of food intakes by individuals 1994 1996. Am J Clin Nutr 2000;71(3):774-80.

140. Phillips EL, Arnett DK, Himes JH, McGovern PG, Blackburn H, Luepker RV. Differences and trends in antioxidant dietary intake in smokers and non-smokers, 1980-1992: The Minnesota Heart Survey. Ann Epidemiol 2000;10(7):417-23

141. Järvinen R, Knekt P, Seppänen R, Reunanen A, Heliövaara M, Maatela $\mathrm{J}$, et al. Antioxidant vitamins in the diet: Relationships with other personal characteristics in Finland. J Epidemiol Community Health 1994;48(6):549-54.

142. Slesinski MJ, Subar AF, Kahle LL. Trends in use of vitamin and mineral supplements in the United State: The 1987 and 1992 National Health Interview Surveys. J Am Diet Assoc 1995;95(8):921-3.

143. Block G, Cox C, Madans J, Schreiber GB, Licitra L, Melia N. Vitamin supplement use, by demographic characteristics. Am J Epidemiol 1988;127(2):297-309.

144. Zondervan KT, Ocké MC, Smit HA, Seidell JC. Do dietary and supplementary intakes of antioxidants differ with smoking status? Int J Epidemiol 1996;25(1):70-9.

145. Osler M. The food intake of smokers and nonsmokers: The role of partner's smoking behavior. Prev Med 1998;27(1):438-43.

146. Greco AM, Gentile M, Di Filippo O, Coppola A. Study of blood vitamin $\mathrm{C}$ in lung and bladder cancer patients before and after treatment with ascorbic acid. A preliminary report. Acta Vitaminol Enzymol 1982;4(1-2):155-62.

147. Anthony HM, Schorah CJ. Severe hypovitaminosis C in lungcancer patients: The utilization of vitamin $\mathrm{C}$ in surgical repair and lymphocyte-related host resistance. Br J Cancer 1982;46(3):354-67.

148. Basu TS, Schorah CJ. Vitamin C in Health A Disease. London: Croom Helm; 1982. p. 32, 15, 66-82. 